\title{
Keseimbangan Model Pengelolaan Dana Desa untuk Meningkatkan Kesejahteraan Masyarakat Pesisir Kabupaten Bonebolango \\ Mattoasi $^{1{ }^{1 *}}$ Candra Cuga $^{2)}$ Muhammad Sarlin $^{3)}$ Sudirman $^{4)}$ \\ ${ }^{1), 4)}$ Fakultas Ilmu Ekonomi, ${ }^{2), 3)}$ Fakultas Ilmu Pendidikan Universitas Gorontalo \\ *E-mail corresponding author: mattoasi@ung.ac.id
}

Received: 24-02-2021;

Accepted: 08-04-2021;

Available online: 30-04-2021

Ecoplan Vol. 4 No. 1, April 2021, hlm 21-31.

\section{ISSN p: 2620-6102}

e: 2615-5575
Abstract - Village funds distributed to every village, especially in Bone Bolango District, are for development purposes and community empowerment. This study aims to determine the balance model of village fund management through Village-Owned Enterprises (Kemendes PDTT, 2019). The research method used is a mixedmethod (mix-method) by recording quantitative data and qualitative data through in-depth interviews for any information given to village heads and village officials in Bone Bolango District, Gorontalo Province. The results showed that community involvement in creating balance is fundamental to realizing a prosperous society. Although, on the other hand, the problem of managing village funds is that they are not maximally used to incubate poverty, have not been on target, or have not matched the potential of the village; the focus of development is still oriented towards infrastructure, which is still found in the field.

\section{Community Welfare.}

Abstrak - Dana desa yang disalurkan kepada setiap desa khususnya di Kabupaten Bone Bolango selain untuk pembangunan juga diperuntukkan untuk pemberdayaan kepada masyarakat. Penelitian ini bertujuan untuk mengetahui model keseimbangan pengelolaan dana desa melalui Badan Usaha Milik Desa (Kemendes PDTT, 2019). Metode penelitian yang digunakan metode campuran (Mix-Methode) dengan menyatatukan data kuantitatif dan data kualitatif melalui wawancara secara mendalam bagi setiap informasi kepada kepala desa dan perangkat desa yang ada di Kabupaten Bone Bolango Provinsi Gorontalo. Hasil penelitian menunjukkan bahwa penglibatan masyarakat dalam menciptakan keseimbangan merupakan hal fundamental untuk mewujudkan masyarakat sejahtera. Disisi lain, permasalahan pengelolaan dana desa yaitu penggunaan yang belum maksimal untuk menetaskan kemiskinan, belum tepat sasaran atau belum sesuai dengan potensi desa, fokus pembangunan masih beriorientasi pada infrastruktur masih ditemukan di lapangan.

Kata Kunci: Keseimbangan; Pengelolaan; Kesejahteraan Masyarakat Pesisir 


\section{PENDAHULUAN}

Desa sebagai wilayah terkecil secara administrasi dari negara dan berada dibawah kecamatan, ditinjau dari jumlah penduduk juga paling rendah dengan penduduk yang bersifat homogen (UUD No. 6 Tahun 2014, Kartohadikusumo; 2004). Meskipun wilayahnya paling kecil, desa diberikan wewenang untuk mengelola sumber daya secara mandiri melalui pendanaan pemerintah pusat dan pemerintah daerah. Pembangunan Desa, sesuai yang diamanatkan dalam Undang-undang No 6 Tahun 2014 tentang Desa, bertujuan meningkatkan kesejahteraan dan kualitas hidup masyarakat desa serta penanggulangan kemiskinan melalui: (1) penyediaan kebutuhan dasar; (2) pembangunan sarana dan prasarana; (3) pengembangan potensi ekonomi lokal; dan (4) pemanfaatan Sumber Daya Alam (SDA) Lingkungan secara keberlanjutan. Untuk mencapai tujuan pembangunan desa dilakukan melalui pendekatan "desa membangun" dan "membangun desa"(Permendesa No. 2 tahun 2016).

Untuk mewujudkan amanat undang-undang tersebut maka perlu pengelolaan yang tepat dan juga sesuai dengan kebutuhan masyarakat, dengan mengimplementasikan Peraturan Menteri Dalam Negeri No. 20 Tahun 2018 tentang penggunaan dana desa dengan perbandingan $60 \%$ untuk pemberdayaan dan $40 \%$ untuk pembangunan fisik. Fenomena lapangan menujukkan bahwa pengelolaan dana desa mengalami perubahan dimensi sasaran yakni pembangunan fisik lebih dominan dibandingkan dengan pemberdayaan masyarakat (Julianto, 2017). Penggunaan dana desa menurut Radio Republik Indonesia (RRI)(2019) menunjukkan bahwa penggunaan dana desa masih terpusat pada pembangunan infrastruktur yang masif sedangkan untuk usaha ekonomi hanya 8\%. Hal ini juga didukung berbagai fakta riset (Inten \& Liliana , 2017; Sulis, 2017) mengungkapkan bahwa penggunaan dana desa lebih cenderung kepada pembangunan fisik, selain itu (Boedijono, Wicaksono, Puspita, Bidhari, Kusumaningrum, Asmandani, 2018). Mendapatkan bahwa $80,51 \%$ digunakan untuk pembangunan. Dari hasil ini kita mengetahui bahwa pemberdayaan masyarakat belum mendapatkan perhatian serius dari pemerintah desa termasuk desa yang ada di Kabupaten Bonebolango propinsi Gorontalo.

Data Badan Statistik menempatkan Gorontalo dalam Indeks Pembangunan Manusia Dalam perkembangannya, Indeks Pembangunan Manusia (IPM) Gorontalo terus meningkat setiap tahunnya dan pada tahun 2017 mencapai 67,01. Namun demikian, level IPM Gorontalo tersebut termasuk ke dalam kategori menengah ke bawah atau lebih rendah dibandingkan dengan provinsi lain di wilayah Sulawesi, Maluku dan Papua. Oleh karena itu, diperlukan kebijakan-kebijakan yang mampu meningkatkan kualitas pengembangan manusia seperti memperbaiki kualitas pendidikan, kesehatan dan pendapatan, sehingga kesejahteraan akan merata dan jurang kesenjangan antara kaya dan miskin dapat dipersempit, (BPS Gorontalo, 2019), Sebagai Provinsi yang memiliki 657 Desa yang tersebar di enam kabupaten dan kota dengan mayoritas status desanya tertinggal terutama pada desa-desa pesisir (Ditjen PPMD; 2018). Kondisi ini seharusnya menjadi perhatian agar semua desa terutama yang ada di daerah pesisir dapat meningkatkan statusnya sebagai standar yang digunakan untuk mengukur indeks "'desa membangun" (UUD No. 6 Tahun 2014)

Dari berbagai persoalan tersebut maka perlu dilakukan pengelolaan sumber daya atau potensi desa yang seimbang yang bersifat partisipatif dan kolaboratif antara pemerintah dengan masyarakat sebagai sasaran untuk peningkatan kesejahteraan di wilayah pesisir Provinsi Gorontalo. Oleh karena itu, dibutuhkan analisis terhadap faktor yang mempengaruhi partisipasi masyarakat agar berkelanjutan (Tumbel, 2017). Untuk itu, penelitian ini hendak menelusuri berbagai masalah pengelolaan dana desa dalam upaya menciptakaan kesejahteraan masyarakat khususnya diwilayah pesisir Kabupaten Bonebolango.

Kesejahteraan masyarakat selama ini telah menjadi perhatian pemerintah melalui program "Desa Membangun" sebagai jargon membangun dari pesisir wilayah Indonesia, akan tetapi untuk menunjang hal tersebut diperlukan pengelolaan sumber daya yang memadai dan memiliki kesesuaian dengan potensi desa dan kebutuhan masyarakat. Untuk itu pelibatan masyarakat untuk menciptakan keseimbangan menjadi hal fundamental untuk mencapai kesejahteraan masyarakat. Berbagai masalah telah terjadi dengan pengelolaan dana desa dari penggunaan yang belum optimal untuk menentaskan kemiskinan, belum tepat sasaran atau belum sesuai dengan potensi desa, fokus pembangunan masih terfokus pada infrastruktur sehingga masalah-masalah ini belum menciptakaan keseimbangan pengelolaan dana desa. Karenanya dibutuhkan kajian mendalam tentang masalah yang terjadi dalam pengelolaan dana desa dalam meningkatkan kesejahteraan masyarakat khususnya wilayah pesisir Kabupaten Bonebolango. 


\section{TINJAUAN PUSTAKA}

Keseimbangan penggunaan dana desa menjadi penting, karena selain aspek pembangunan fisik juga dituntut untuk memberdayakan masyarakat melalui Badan Usaha Milik Desa (BUMDes) (Kemendes PDTT, 2019) sebagai aktivitas yang lebih dominan dibandingkan dengan pembangunan phisik. Urgensi penggunaan dana desa ini juga sejalan dengan beberapa kajian antaranya Jensen dan Meckling (1976); Tricker (1984) dan Williamson (1985) serta Donaldson (1985) bahwa struktur tata kelola pemerintahan yang sesuai dapat memberi dampak terhadap pengelolaan sumber daya organisasi untuk masyarakat sebagai prinsipal yang telah mengamanahkan kepada pemerintah (Agen). Sejalan dengan kehendak pemerintah untuk mengelola sumber daya organisasi dengan tujuan untuk meningkatkan kesejahteraan kepada masyarakat, maka terdapat beberapa hal yang perlu dilakukan khususnya dalam pengelolaan dana desa. Selain aspek perencanaan, pelaksanaan, penatausahaan, pelaporan, serta pertanggungjawaban seperti yang dihendaki dalam (Permendagri Nomor 113 Tahun 2014), dana desa pengelolaannya harus memperhatikan aspek keterbukaan dan pertanggungjawaban yang sesuai; partisipasi masyarakat dan tertib anggaran selalu berdasarkan peraturan yang berlaku.

Beberapa dampak nyata di masyarakat menggambarkan sebuah konsekuensi dari pengelolaan dan penggunaan Dana Desa, karena sesungguhnya "Implementasi suatu kebijakan dalam pengertian yang luas merupakan alat administrasi hukum dimana berbagai aktor, organisasi, prosedur, dan teknik yang bekerja bersama-sama untuk menjalankan kebijakan guna meraih dampak atau tujuan yang diinginkan (Lester \& Stewart, 2000).

Kebijakan Dana Desa ditetapkan pemerintah melalui Peraturan Pemerintah No. 60 Tahun 2014 tentang Dana Desa dimaksudkan untuk mewujudkan Desa kuat, maju, mandiri, dan demokratis, sehingga untuk itu peran dan potensi desa harus diberdayakan (Jamaluddin, Sumaryana, Rusli, \& Buchari, 2018). Pemberdayaan masyarakat di desa harus dapat dikelola dan diorganisir dengan baik. Sejalan dengan kehendak pemerintah untuk mengelola sumber daya organisasi dengan tujuan untuk meningkatkan kesejahteraan kepada masyarakat, maka terdapat beberapa hal yang perlu dilakukan khususnya dalam pengelolaan dana desa. Selain aspek perencanaan, pelaksanaan, penatausahaan, pelaporan, serta pertanggungjawaban seperti yang dihendaki dalam Permendagri Nomor 113 Tahun 2014, pengelolaan dana desa harus memperhatikan aspek keterbukaan dan pertanggungjawaban yang sesuai, partisipasi masyarakat dan tertib anggaran selalu berdasarkan peraturan yang berlaku.

Ada beberapa kajian yang relevan terhadap implementasi Permendagri No. 113 Tahun 2014 di dalam pengelolaan dana desa. Intan dan Liliana (2015) menemukan bahwa pengelolaan dana desa belum maksimal sesuai dengan harapan karena sumber daya manusia di desa masih terbatas. Tidak berbeda dengan hasil penelitian lain seperti Blane (2015) menemukan bahwa pengelolaan dana pemerintah pada setiap level akan bermasalah jika tidak terdapat pengembangan sistem yang digunakan termasuk di dalam pemerintahan desa. Sistem yang dimaksudkan disini mulai tahap perencanaan, proses hingga tahap evaluasi program Hal ini juga sejala dengan hasil penelitian Lasmi \& Verni (2020) bahwa setiap dana desa berpengaruh terhadap kesejahteraaan masyarakat.

Pengelolaan dana desa yang lebih baik akan berujung kepada pelaporan, pertanggungjawaban dan interpretasi terhadap laporan yang dihasilkan. Hal ini sejalan dengan beberapa hasil penelitian yang menyatakan bahwa pengelolaan keuangan yang baik diawali dari perencanaan sampai pada tahap pertanggungjawaban dan interpretasi, sehingga program yang telah dirancang berdasarkan program telah sesuai dan dilaksanakan berdasarkan skala prioritas di dalam memenuhi kebutuhan masyarakat (I Wayan, I Nyoman \& Iyus, 2016; Justita, 2016; Abu, 2015); Nurul \& Iin, 2017; Astuti \& Yulianto, 2016; Sulis, 2017). Demikian halnya yang dikemukakan oleh Abidin (2015) bahwa kelembagaan setiap desa dapat mendukung terlaksananya pengelolaan dana desa yang maksimal. Beberapa syarat menurut Abidin (2015) pengelolaan dana desa diharapkan harus terpenuhi yaitu akuntabilitas, transparansi serta partisipasi masyakat sangat diperlukan serta peningkatan sumber daya manusia pada masing-masing desa serta koordinasi dengan pemerintah kecamatan agar pengelolaan dana desa sesuai dengan peruntukannya (Abidin, 2015).

Sejalan beberapan uraian berkaitan pengelolaan dana desa, juga telah dikemukakan oleh Azis (2016) yang menyatakan bahwa penggunaan dana desa belum efektif karena kapasitas dan kapabilitas pemerintah dan pegawainya masih rendah serta penglibatan masyarakat sangat rendah. Hasil penelitian Thomas (2013) dan Yuyun (2015) menunjukkan bahwa terdapat berbagai hal yang menyebabkan pengelolaan dana desa belum optimal sebagaimana amanah Permendagri Nomor 113 Tahun 2014. Hal ini disebabkan oleh pembangunan fisik menjadi perhatian utama, selain sumber daya manusia dan koordinasi kurang maksimal. 


\section{METODE PENELITIAN}

Penelitian ini merupakan penelitian mix methods, yaitu penelitian dengan menggunakan dua penedekatan penelitian yakni kualitaif dan kuantitatif. Penelitian capuran merupakan penelitian yang mengkobinasikan antara penelitian kualitatif dan kuantitatif, (Creswell, 2010; Sugiyono, 2011). Untuk pendekatan kualitatif dikerjakan dengan menggunakan pendekatan sosiologis dan analisis memori kolektif (Berg, 2007; Biernacki, 2005; Zerubavel, 2003; Nash, 2001). Tujuan utama yang hendak dihasilkan adalah rekonstruksi sejumlah peristiwa, dokumen, yang terjadi dimasyarakat selama penggunaan dana desa dalam mencapat kesajahteraan. Selain itu juga untuk melihat relasi antara pemerintah desa dengan masyarakat dalam bersama-sama dalam melihat potensi desa, merumuskan kegiatan, kebijakan serta dampak kebijakan pemerintah pada masyarakat. Pendekatan kualitatif di gunakan peneliti untuk menemukan tema-tema konflik, stratifikasi sosial dan interes masyarakat dan pemerintah desa dalam pengelolaan dana desa dan kesejahteraan masyarakat pesisir Kabupaten Bonebolango.

\section{HASIL DAN PEMBAHASAN}

Pemanfaatan dana desa mendapat perhatian bagi peneliti untukmendapatkan gambaran tentang pemanfatan dana desa yang selama ini telahdilakukan oleh pemerintah desa, dari hasil paparan data tentang temuan penelitimaka temuan tersebut akan dibahas secara empris dengan melihat dari berbagaiperspektif pengetahuan. Berikut ini pembahasan dari hasil temuan peneliti.

\section{Pengalaman Kepala Desa dan Kemampuan Membaca Potensi sebagai Penunjang dalam Pengelolaan Dana Desa}

Kemampuan dan pengalaman kepala desa menjadi faktor yangmemberikan dampak baik terhadap pengelolaan dana desa. Dapat disimpulkan bahwa semua kepala desa yang menjadi subjek dari penelitian ini merupakan orang yang telah memiliki pengalaman dalam memimpin setiap organisasi. Selain pengalaman yang dimiliki,mayoritas kepala desa memiliki gelar S1 dan S2 sehingga menjadi daya tarik masyarakat, karena pengetahuan dan pengalamannya diharapkan mampu mengelola sumber-sumber ekonomi yang tersedia untuk kesejahteraan masyarakat desa itu sendiri. Kondisi ini sesuai dengan pendapat Rofi bahwa pengalaman kerja seseorang akan banyak berpengaruh terhadap keahlian dan keterampilan yang dimilikinya (Nurrofi, 2012).

"Pengalaman juga itu penting untuk menopang menjadi pemimpin pak kebetulan saya punya pengalaman sejak di Manado sebagai penggerak masyarakat di kompleks saya untuk gotongroyong bekerja sama memeperbaiki ekonomi di sana, saya di sana kasih kursus orang-orang terutama anak muda untuk menjahit daripada nganggur dan berhasil jadi saya tahu bagaimana melibatkan masyarakat pak, di Desa ini saya juga sudah paham betul kondisi Desa pak karena saya sudah lama menjadi Guru di sini jadi saya tahu betul kondisi masyarakat di Desa ini dan apa yang dibutuhkan saat ini". (Ayah Botu Barani;W/03/20-042020). “...Ayahanda ini sudah lama disini pak, dia ini sebelum jadi ayahanda di sini dulunya itu guru SD disini terus dia pensiun beberapa tahun lalu, baru mencalonkan jadi ayah di sini jadi so lama di sini sudah tahu tentang desa ini, memang ayah ini belum lama dilantik pak jadi ayah. Kalau lihat ayah ini ya bagus pak selalu bekerja membantu masyarakat tidak ada perbedaan semua 14 orang dapat bantuan, banyak kegiatan masyarakat juga, jadi biar masih baru tapi ayah ini sudah tahu desa ini makanya masyarakat banyak yang pilih dia ini. (NA; W/07/20-04-2020) ....ayah ini sudah lama di sini pak, dari guru di sini, terus jadi pengawas jadi kepala dinas, baru S2 lagi, makanya masyarakat pilih dia jadi ayahanda d isini, siapa yang tidak pilih dia pak S2 pasti pintar pak, sudah tahu juga desa ini karena sudah lama dari tahun 90 an pak, pensiunan kepala dinas lagi, makanya masyarakat senang pilih karena pendidikannya pak. (NS;09/10-102020).

Berkaitan dengan tingkat pengetahuan dan pengalaman yang dimiliki oleh seseorang termasuk kepala desa yang diharapkan dapat mengelola sumber daya desa, maka hal ini juga seirama dengan 
pemikiran Spencer and Spencer dalam Sudarmanto (2009) kompetensi merupakan karakteristik dasar perilaku individu yang berhubungan dengan kriteria acuan efektif dan atau kinerja unggul di dalam pekerjaan atau situasi. Pemikiran Spencer and Spencer (2008) yang di dukung dari hasil penelitian ini juga telah dikuatkan oleh Dessler (2000); Sudarmanto (2009); Stoner \& Wankel (1996) bahwa selain pendidikan, pelatihan merupakan salah satu bagian dari langkah-langkah proses manajemen sumberdaya manusia dalam organisasi.

\section{Kesadaran Masyarakat dan Partisipasi Masyarakat dalam Pengelolaan Berbagai Potensi Desa}

Berdasarkan hasil penelitian mengenai kesadaran masyarakat dan partisipasi dalam pengelolaan dana desa, menunjukkan bahwa di ke empat lokasi penelitian (Desa Molotabu; Desa Botutonuo; Desa Biluango dan Desa Botuberani) bahwa kesadaran dan pastisipasi masyarakat di dalam meningkatkankeseimbangan pengelolaan dana desa belum terwujud secara maksimal yang menyebabkan masih belum terjadinya perubahan pada diri masyarakat. Namun demikian kesadaran dan partispasi masyarakat tidak memberi dampak terhadap keseimbangan pengelolaan dana desa karena setiap bantuan yang telah diberikan habis begitu saja tanpa tindak lanjut dari masyarakat itu sendiri dalam mengembangkan usaha. Kondisi ini berbeda dengan pendapat Gaventa \& Valderma (2001) menegaskan bahwa "partisipasi masyarakat telah mengalihkan konsep partisipasi menuju suatu kepedulian dengan berbagai bentuk keikutsertaan warga dalam pembuatan kebijaksanaan dan pengambilan keputusan di berbagai gelanggang kunci yang mempengaruhi kehidupan warga masyarakat.

Masalah utama sebenarnya yang kami hadapai pak kesedaran masyarakat yang sangat kurang kalau dikasih bantuan mereka tidak berpikir bagaimana keberlanjutan bantuan tersebut kadang dikasih bantuan ya sudah habis itu bantuan pak, mereka berpikir nanti dapat lagi bantuan, mereka tidak berpikir setelah dikasih bantuan itu harapannya dapat membantu untuk memperbaiki ekonomi mereka misalnya dari pra sejahtera ke sejahtera kalau mereka dikasih tahu mereka cuek saja pak ini masalah yang saya hadapi di lapangan, dan mereka selalu berharap dapat bantuan lagi ini rumah-rumah bagus pak kalau lihat tapi ini ekonomi susah semua pak makanya saya heran bangun rumah bagusbagus cuma ekonominya susah makannya ubi heran saya, jadi merubah pemikiran masyarakat dulu untuk diberikan kesadaran untuk keberlanjutan ekonomi pak. (Ayah Botu Berani;W/03/20-04-2020); ....yang susah itu di sini masyarakat susah diajak kerjasama makanya selalu mis komunikasi dengan masyarakat pak, sehingga sering kali ketidakmampuan masyarakat dalam mengelola keuangan UMKM, masyarakat itu kurang sadar dengan kondisi yang ada, pernah ada bantuan di sini tentang usaha kerajinan batu alam tapi ya Cuma habis dimodal pak, (Ayah Desa Botutonuo;W/04/01-06-2020)

Konsep Gaventa \& Valderma (2001) yang ditemukan di dalam lokasi penelitian mendapati bahwa jika masyarakat memiliki kepedulian terhadap program pemerintah di desa maka hal tersebut akan memberikan keberhasilan,yang terbukti melalui peternakan sapi masyarakat di Desa Molotabu yang kandangnya dibuat bersama oleh kelompok telah berhasil digulirkan kepada masyarakat yang memerlukan sehingga memberi dampak kepada mereka. Hasil penelitian ini sesuai dengan konsep Durkheim (1957) bahwa masyarakat agraris bersifat homogen, para anggotanya melakukan kegiatan yang relatif sama sehingga devision of labor-nya menjadi sangat sederhana. Di samping itu,masyarakat tersebut memiliki nilai-nilai, ide, aspirasi atau tujuan hidup yang juga relatif sama. Kesederhanaan cara pikir masyarakat agraris ini tercermin pada tumbuh kembangnya suatu bentuk kesadaran kolektif atau aktivitas kebersamaan yang dimiliki menjadi kuat (Septiarti, 1994). Dengan demikian, betapa pentingnya komunikasi yang kolaboratif dilakukan. 


\section{Asistensi Berkala/Pelatihan dan Pengawasan Bagi Kelompok Masyarakat sebagai Sasaran dalam Pengelolaan Dana Desa}

Berkaitan dengan keseimbangan pengelolaan dana desa khususnya di desa pesisir Kecamatan Kabila Bone, dari hasil penelitian ini menunjukkann bahwa terdapat 3 hal penting di dalam memaksimalkan penggunaan dana desa baik proporsi penggunaan maupun efektivitas pengunaannya yaitu asistensi, pelatihan dan pengawasan. Hasil penelitian ini juga sejalan kehendak pemerintah melaluiUndang-Undang Nomor 6 Tahun 2014; Permendagri Nomor 20 Tahun 2018 tentang efektivitas pengelolaan dana desa.

Kami di sini juga perlu dana untuk pelatihan pak bos anggaran itu harus ada cuma sekarang belum ada jadi saya mau masyarakat yang diberikan bantuan itu diberikan bantuan pelatihan juga jangan dilepas begitu saja ini pengalaman saya di Manado dan berhasil pak Alhamdulillah, dan terus didampingi pak masyarakat itu jangan dipelas sampai betul-betul mahir dan juga mau untuk melakukannya sendiri bila perlu mereka sampai mahir mendesain kebetulan saya ini akan memberikan bantuan dan juga sudah ada bantuan mesin jahit cuma belum bisa dipake dengan baik belum ahli juga tidak tepat sasaran pak, nelayan dikasih mesin jait untuk apa akhinya cuma tataru saja itu sebenarnya itu untuk apa tapi ya nanti kita akan berikan 19 pelatihan mereka pak terutama di sini ini akan mudah banyak yang nganggur nanti itu yang kita kasih mesin jahit dan juga pelatihan sampai mereka mahir desain dan menghasilkan pak biar ini anak muda jangan cuma minum-minum saja dan kesana kemari tidak jelas. (Ayah Botu Berani;W/03/20-042020).Yang dibutuhkan di desa sebenanrya pak orang yang ahli misalnya di sini kan banyak kemiri Cuma untuk mengolanya ini masyarakat di sini belum bisa jadi Cuma berkebun lalu petik jual Cuma begitu saja sama juga madu pak ini Cuma diambil di hutan baru jual begitu saja tanpa pengelohan, pengemasan yang baik, saya sebagai kepala desa maunya itu ada ahli atau pendamping untuk mengelola hasil kebun atau madu dengan benar sampai kepada penjual kalau itu ada pak pasti bagus dan masyarakat akan terbantu, karena yang susah ini pemasaran dan pengelolaan pak jadi masyarakat ya jual begitu saja. (Ayah Biluango; W/02/20-04-2020)

Aktivitas asistensi, pelatihan dan pengawasan sebagai aspek penting di dalam pengelolaan dana desa yang belum diterapkan dalam lokasi penelitian ini juga sejalan dengan Bima, Kamal, \& Djanggih (2020) yang mengatakan bahwa pengelolaan dana desa harus menjadi prioritas sehingga perlu pola preventif di dalam pengelolaan dana desa agar tidak terjadi kebocoran seperti yang telah dilansir oleh Indonesian Corruption Watch (2015-2018). Perlunya asistensi, pelatihan danpengawasan juga sejalan dengan Badan Pewangasan Keuangan dan Pembangunan (2020) bahwa akuntabilitas pengelolaan dana desa harus ditingkatkan agar mencapai sasaran yang lebih efektif dan efisien. Demikian juga Mulyani (2020) mengatakan bahwa pengetatan pengelolaan keuangan desa wajib dilakukan agar sesuai dengan pemanfaatannya.

\section{Ketepatan Penggunaan Dana Desa Sesuai dengan Potensi Desa}

Di dalam penelitian ini ditemukan bahwa selama ini penggunaan dana desa belum maksimal dan sesuai dengan potensi desa yang ada. Hal tersebut tergambar melalui hasil penelitian yang telah dilakukan, ketidak sesuaian ini memberikan dapat negatif bagi masyarakat diantaranya dana atau bantuan sebagai swadaya masyarakat tidak berfungsi secara maksimal, hal ditemui dalam penelitian yakni bahwa dana desa yang digunakan untuk pembedayaan masyarakat desa belum tepat sasaran kasus yang dijumpai adalah nelayan mendapat mesin jahit hal ini membuat mandeknya kegiatan ekonomi masyarakat karena ketidaktepatan bantuan dengan sasaran.

Pengelolaan dana desa selama ini belum tepat pak menurut saya karena saya melihat tahun-tahun sebelumnya itu begitu kan saya baru dilantik empat bulan lalu dan saya sudah 
lama di sini pak sejak tahun 90-an sudah di sini jadi saya tahu ini desa. Coba ini lampu listrik jalan dulu bangun ini lampu untuk apa desa pak, desa tidak butuh ini nanti malam ini desa pak macam kota pak terang sekali dan anggarannya ini besar menurut saya ini belum tepat sasaran pak, sekarang jadi susah juga ini kan pake pulsa pak harus beli dan dananya besar sementara dana desa tidak bole untuk beli pulsa jadi sekarang tinggal dari masyarakat itu patungan beli pulsa, kalau tidak ada ya tidak menyala, saya tahu ini pak kan proyek jadi ada untungnya jadi penting bagi saya itu harus utama sasaran yang dibutuhkan masyarakat, mesin jahit kasih nelayan kan untuk apa, lalu yang dapat bantuan itu-itu saja atau keluarga sendiri selama ini itu yang terjadi pak. (Ayah Botu Barani;W/03/20-04-2020).....terdapat lampu jalan yang berada di Desa Botu Barani yang nota bene ini merupakan jalan tran yang pendanaannya seharusnya bukan mejadi tanggungjawab desa, lampu jalan ini berjejer sepanjang jalan desa Botu barani, menurut ayah botu barani bahwa listrik ini dibayai oleh dana desa, dan listriknya menjadi tanggujawab masyarakat juga, karena ini menurutnya tidak tepat sasaran, salah satu tiang listrik berdiri tepat samping kiri kantor Desa Botu berani. O./03/20-04-2020

Selain hal tersebut kasus lain yang ditemui dalam penelitian ini adalah pembangunan fisik juga tidak sesui dengan kebutuhan bahkan merugikan masyarakat desa kasus ini dijumpai pada masyarakat desa Botuberani berupa pembangunan lampu jalan desa yang berada pada jalan trans yang nota bene wilayah tanggung jawab provinsi hal ini juga terjadi di desa Biluango, dan sekarang hal ini merugikan masyarakat karena pembiyaan listrik untuk sekarang dibebankan pada masyarakat, hal ini tejadi karena penggunaan anggaran yang belum tepat dikelola selama ini oleh pihak terkait.

Hasil penelitian ini menunjukkan bahwa penggunaan dana desa belum tepat sasaran sehingga berpengaruh terhadap kesejateraan masyarakat. Kondisi ini tidak sesuai dengan kehendak pemerintah seperti yang diamanahkan dalam Undang-Undang Nomor 6 Tahun 2014; Permendagri Nomor 20 Tahun 2018 tentang efektivitas pengelolaan dana desa. Demikian juga dijelaskan oleh Bambang Brodjonegoro dalam harian Kontan 11 Januari (2016) bahwa peruntukan dana desa (DD) sering disalahgunakan oleh aparat desa, sehingga manfaat bagi masyarakat desa tidak tercapai.

\section{Pemanfaatan Dana Desa Disesuaikan dengan Asas Proporsional dan Kajian Terlebih Dahulu}

Asas proporsional dan juga kajian terlebih dahulu oleh ahli maupun pemerintah menjadi bagian yang tidak boleh diabaikan begitu saja, temuan penelitian ini merujuk bahwa selama ini pemberian bantuan pada masyarakat belum proporsional jumlahnya dan juga dilakukan kajian terlebih dahulu. Hasil wawancara dari berbagai pihak ditemukan bahwa asas ini diabaikan dan belum dilaksanakan dengan baik, para kepala desa menginginkan bahwa kajian diperlukan untuk menentukan pemetaan terkait dengan potensi desa yang dimiliki sehingga pemanfataan dana desa ini sesuai dan dapat meningkatkan kesejahteraan masyarakat desa.

....sebenarnya yang utama itu yang perlu dilakukan itu pak kajian dulu, maksudnya melakukan kajian terhadap potensi desa terus didaftar sebagai sasaran nanti untuk membangun desa ini, itu dulu utamanya dengan demikian mo dapa tahu itu sasaran pak, kalau itu udah ada bahwa potensi desa ini $A, B, C$... baru kita tentukan anggarannya secara proporsional pak, jadi pembagian dana untuk pemberdayaan itu memperhatikan potensi desa dan secara proporsi pak, misalnya penggurran di sini banyak anak muda dicari sosuli dengan kajian terus diberikan bantuan apa begitu sesuai kebutuhan anak muda itu biar sesuai dan juga menghasilkan pak. Itu yang penting selama ini ditentukan dulu anggaran tanpa kajian lebih dulu pak. (Ayah Botu Barani;W/03/20-04-2020). Untuk memanfatkan Dana desa secara maksimal maka kuncinya yang utama itu tereletak pada Ayahanda (Kepala Desa) karena sebagai pemimpin kita harus adil terhadap masyarakat, selama ini yang sudah dilakukan sebelum saya pembagian untuk pemberdayaan masyarakat belum tepat sasaran misalnya yang terjadi nelayan diberi bantuan mesin jahit, ini namanya tidak tepat sasaran, kemudian kita lihat juga untuk pembagian yang selama ini lebih diutamakan keluarga dengan mengabaikan kebutuhan atau status ekonomi masyarakat dengan 
demikian sebagai seorang Ayah 24 tidak boleh seperti ini. Inilah sebabnya selama ini pemanfatan dana desa belum maksimal sesuai dengan sasaran. (Ayah Botu Barani; W/03/20-04- 2020).

Hasil penelitian ini menunjukkan bahwa proporsi penggunaan keuangan dengan perbandingan $40 \%$ untuk pembangunan dan $60 \%$ persen untuk pemberdayaan belum sepenuhnya dilaksanakan, dan bahkan kenyataan di lapangan menunjukkan bahwa dana belanja pembangunan setiap tahun lebih tinggi dibandingkan dengan dana pemberdayaan. Temuan ini juga berbeda Huru, Harahap dan Nasution (2018) bahwa orientasi penggunaan desa lebih pada aspek pembangunan. Selain itu di dalam buku pintar dana desa (2018) dijelaskan bahwa keberhasilan dana desa maka proporsi pemberdayaan kepada masyarakat harus ditingkatkan. Penyaluran dana desa yang mengalami peningkatan setiap tahun, menurut BPKP (2020) diharapkan lebih memberdayakan masyarakat melalui program menciptakan lapangan kerja; mengatasi kesenjangan, dan dapat mengentaskan kemiskinan pada masyarakat.

\section{KESIMPULAN}

Penelitian ini memberikan pemahaman tentang alur dan pola pemanfaatan dana desa yang selama ini dilakukan, untuk itu sebagai kesimpulan dalam penelitian sebagai temuan dan juga pemodelan tentang keseimbangan pengelolaan dana desa untuk meningkatkan kesejahteraan membutuhkan berbagai varibel diantaranya; 1) pengalaman dan pengetahuan kepala desa sebagai pimpinan di Desa menjadi bagian tersebut karena pengalaman seseorang sangat mempengaruhi kepemimpinan dan juga akan efektif dalam kepemimpinannnya, pengetahuan dalam penelitian ini berhubungan dengan latar belakang pendidikan kepala desa, pendidikan akan memberikan nilai tersendiri bagi masyarakat desa sehingga dalam pengelolaan dana desa akan melibatkan pengetahuan yang telah dimiliki oleh kepala desa; 2) Partisipasi dan kesadaran masyarakat: banyak masyarakat belum menyadari pentingnya keterlibatan mereka dalam pengelolaan dana desa ini sebagai sasaran, partisipasi masyarakat akan memberikan manfaat bagi mereka sendiri sehingga tercapai kesejahteraan itu dengan sendirinya; 3) Asistensi berkala/training/controling bagi kelompok masyarakat sebagai sasaran dalam pengelolaan dana desa: sebagai temuan penting dalam penelitian ini yang menjadi bagai yang menciptakan keseimbangan dalam pengelolaan dana desa; 4) Ketepatan penggunaan dana desa sesuai dengan potensi desa: pengggunaan dana yang selama ini belum maksimal karena belum tepat sasaran akan tetapi keinginan kepala desa baru akan mewujudkan hal ini; 5) Pemanfaatan dana desa disesuaikan dengan Asas Proporsional dan kajian terlebih dahulu; kegiatan dalam pengelolaan dana desa selama ini belum dilakukan secara proporsional dan kajian terlebih dahulu.

Setelah melakukan kajian yang mendalam tentang keseimbangan pengelolaan dana desa maka tim merumuskan berbagai rekomendasi sebagai pertimbangan bagi pemerintah desa dalam mengembangkan berbagai potensi desa melalui dana desa, yaitu: 1) Perlu tim ahli untuk melakukan berbagai kajian terkait dengan pengembangan potensi desa hal ini dapat dilakukan dengan melibatkan perguruan tinggi pada wilayah desa tersebut, hal ini diperlukan untuk memastikan secara empris tentang pengembangan potensi sebelum dilakukan tindakan; 2) Asistensi diperlukan dalam pemberdayaan masyarakat karena salah satu kendala selama ini adalah kurang asistensi dari ahli untuk melakukan asistensi secara berkala bagi masyarakat karena itu pemerintah harus memberikan asistensi kepada masyarakat sebagai sasaran dan berkesinambungan; 3) Pemerintah desa harus aktif memberikan pemahaman agar masyarakat terlibat aktif dan berpartisipasi secara bersama-sama untuk mengembangakan berbagai potensi desa demi peningkatak kesejahteraan bagi masyarakat desa.

\section{DAFTAR PUSTAKA}

Abidin, M. Z. (2015). Tinjauan Atas Pelaksanaan Keuangan Desa dalam Mendukung Kebijakan Dana Desa. Jurnal Ekonomi \& Kebijakan Publik, 6(1), 61-76.

Abu, R. ( 2015). Pengelolaan Alokasi Dana Desa dalam Pembangunan Fisik Desa Krayan Makmur Kecamatan Long Ikis Kabupaten Paser. http://ejournal.ip.fisip-unmul.ac.id/site/wpcontent/uploads/2015/11/eJournal\%20(11-05-15-10-50-31).pdf. 
Astuti, T.P. \& Yulianto. (2016). Good governance pengelolaan keuangan desa menyongsong berlakunya Undang-Undang No. 6 Tahun 2014. Berkala Akuntansi dan Keuangan Indonesia, 1 (1): 1-14.

Azis, N. L. L. (2016). Otonomi Desa dan Efektivitas Dana Desa. Jurnal Penelitian Politik, 13(2), 193211.

Berg, B. (2007). An Introduction to Content Analysis. In: Berg, B.L., Ed., Qualitative Research Methods for the Social Sciences, Allyn and Bacon, Boston, 238-267.

Biernacki, R. (2005). "The event of place in historical sociology". In H.J. Graff., L.P. Moch., P. McMichael \& J. Woesthoff (Eds), Looking Backward and Looking Forward: Perspectives on Social Science History. Madison: University of Wisconsin Press.

Blane D. L. (2015). Decentralising to villages in Indonesia: Money (and Other) Mistakes. https://doi.org/10.1002/pad.1741

Boedijono, Wicaksono, G., Puspita., Y., Bidhari, S., C. Kusumaningrum, N., D., Asmandani, V. (2018). Efektifitas pengelolaan dana desa untuk pembangunan dan pemberdayaan masyarakat desa di kabupaten bondowoso. Jurnal Riset Manajemen dan Bisnis (JRMB) Fakultas Ekonomi Uniat. 4(1). 9 - 20. https://garuda.ristekbrin.go.id/author/view/999113

Creswell, W. J. (2010). Research Design: Pendekatan Kualitatif, Kuantitatif, dan Mixed. Yogykarta: Pustaka Pelajar.

Lasmi \& Verni. (2020). Pengaruh akuntabilitas pengelolaan keuangan alokasi dana desa, kebijakan desa dan kelembagaan desa terhadap kesejahteraan masyarakat pada Nagari Sungai Tanang Kecamatan Banuhampu Kabupaten Agam. Jurnal Ilmu Ekonomi dan Bisnis, 11(1). http://eksis.unbari.ac.id/index.php/EKSIS/article/view/176

Dessler, G. (2000). Human resource management. 8th edition. New Jersey: Prentice-Hall,Inc.

Donaldson, L. (1985). In Defence of Organization Theory, A Reply to the Critics (Cambridge, Cambridge University Press). https://www.coursehero.com/file/p7paqq29/Donaldson-L-1985-In-defence-oforganization-theory-A-reply-to-the-critics/

Gaventa, J. \& Valderama C. 2001. Mewujudkan Partisipasi-21: Teknik Mewujudkan Partisipasi Masyarakat Untuk Abad 21, British Council.https://www.google.com/search?q=permendesa+nomor+2+tahun+2016\&oq=permendesa+ no\&aqs=chrome $4.69 \mathrm{i} 57 \mathrm{j} 015.14456 \mathrm{j} 1 \mathrm{j} 7 \&$ sourceid=chrome \&ie $=\mathrm{UTF}-8$

Hulu, Y., Harahap, R. H., \& Nasution, M. A. (2018). Pengelolaan Dana Desa dalam Pemberdayaan Masyarakat Desa. Jurnal Pendidikan Ilти-Ilmu Sosial, 10 (1), 146-154. http://jurnal.unimed.ac.id/2012/index.php/jupiis

Saputra, I.W., Sujana, I.W. \& Haris, I.A. (2016). Efektivitas Pengelolaan Alokasi Dana Desa (ADD) Pada Desa Lembean Kecamatan Kintamani Kabupaten Bangli Tahun 2009-2014, Jurnal Pendidikan Ekonomi Undiksha, 6 (1), 1-10.

Inten, M. \& Liliana. (2017). Pengelolaan Keuangan Desa. Jurnal Akuntansi Multiparadigma, 8(2), 227 429.

Jamaluddin, Y., Sumaryana, A., Rusli, B., \& Buchari, R. A. (2018). Analisis Dampak Pengelolaan dan Penggunaan Dana Desa terhadap Pembangunan Daerah. JPPUMA Jurnal Ilmu Pemerintahan dan Sosial Politik Universitas Medan Area, 6(1), 14-25. 
Jensen, M.C. and W.H. Meckling. (1976). Theory of the Firm: Managerial Behavior, Agency Costs, and Ownership Structure, Journal of Financial Economics, 3, 305-360.

Julianto, A. (2017). Efektivitas Pengelolaan Alokasi Dana Desa di Kecamatan Sembakung Kabupaten Nunukan (Studi Komparatif di Desa Mambulu dan Desa Pagaluyon). E-Journal PIN. 5(4). http://ejournal.pin.or.id/site/1415

Justitia, D (2016). Pengaruh Akuntabilitas Pengelolaan Keuangan Alokasi Dana Desa, Kebijakan Desa, dan Kelembagaan Desa terhadap Kesejahteraan Masyarakat. Jurnal Ilmiah Bisnis dan Ekonomi Asia, 10(2), 26-32.

Kartohadikusomo. 1984. Desa. Jakarta: Balai Pustaka

Kemendes PDTT. (2019). Kemendes PDTT Konsolidasikan Percepatan Program Tahun 2019. https://news.detik.com/berita/d-4410306/kemendes-pdtt-konsolidasikan-percepatan-programtahun-2019?_ga=2.157263803.1202207018.1566112987-1319973758.1566112987

Kementerian Keuangan Republik Indonesia. (2018). Buku Pintar Dana Desa. https://www.kemenkeu.go.id/media/6749/buku-pintar-dana-desa.pdf

Lester, J.P. \& Stewart, J. (2000). Public Policy: an Evolutionary Approach. Australia: Wodsworth, Second Edition.

Menteri Desa, Pembangunan Daerah Tertinggal, dan Transmigrasi Republik Indonesia. No.2 Tahun (2016). Peraturan Menteri Desa, Pembangunan Daerah Tertinggal, dan Transmigrasi Republik Indonesia.

Bima, M.R., Kamal, M., Djanggih, H. (2020). Pelatihan dan penyuluhan pengelolaan Alokasi Dana Desa (ADD). Jurnal Inovasi Hasil Pengabdian Masyarakat (Jipemas), 3(1), 63-77. http://Riset.Unisma.Ac.Id/Index.Php/Jipe

Nash, K. (2001). The Cultural Turn in Social Theory: Towards A Theory of Cultural Politics. Sociology, $35(1), 77-92$.

Nurrofi, A. (2012). Pengaruh disiplin kerja dan pengalaman kerja terhadap prestasi kerja karyawan pada departemen produksi PT. Leo Agung Raya Semarang. Jurnal Ilmu Manajemen dan Akuntansi Terapan, 13 (1), h: 1-4.

Nurul, H. \& Iin,W. (2017). Akuntabilitas Pengelolaan Dana Desa (DD) Studi Kasus pada Desa Wonodadi Kecamatan Ngrayun Kabupaten Ponorogo. Jurnal Aksi, 2 (2). http://journal.pnm.ac.id/index.php/aksi/article/view/114.

Permendagri 20 Tahun (2018) Tentang Pengelolaan Keuangan Desa. https://www.jogloabang.com/desa/permendagri-no-20-th-2018-pengelolaan-keuangan-desa

Radio Republik Indonesia, 2 Mei, (2019). Dana Desa untuk Pemberdayaan Ekonomi Kerakyatan Baru $8 \%$.

http://rri.co.id/post/berita/668159/ekonomi/dana_desa_untuk_pemberdayaan_ekonomi_kerakyatan _baru_8.html

Wisni, S. (1994). Transformasi Sosial Masyarakat dalam Perspektif Strukturalisme - Fungsionalisme Suatu Tinjauan Sosiologis. Jurnal Cakrawala Pendidikan, Nomor 3, Tahun XUI, November, 127138.

Stoner, James A.F., \& Charles Wankel (1986). Management, Third Edition, Prentice-Hall International, Inc., Englewood Clffes, New Jersey.

Sudarmanto (2009). Kinerja dan Pengembangan Kompetensi SDM. Yogyakarta: Pustaka Pelajar.

Sugiyono. 2011. Metode Penelitian Kuantitatif, Kualitatif dan R\&D. Bandung: Afabeta 
Sulis.S. (2017). Efektivitas Pengalokasian Dana Desa di Desa Karang Tunggal Kecamatan Tenggarong Seberang Kabupaten Kutai Kartanegara. E-Journal Administrasi Negara. 5(3).

Thomas. (2013). Pengelolaan Alokasi Dana Desa Dalam Upaya Meningkatkan Pembangunan di Desa Sebawang, Kecamatan Sesayap, Kabupaten Tana Tidung. Jurnal Pemerintahan Integratif, 1, $51-$ 64.

Tricker, R.I. (1984). Corporate Governance: Practice, Procedures and Powers in British Companies and Their Boards of Directors (Aldershot, Hants., Gower). https://www.worldcat.org/title/corporategovernance-practices-procedures-and-powers-in-british-companies-and-their-boards-ofdirectors/oclc/10505517.

Tumbel, S., M. (2017). Partisipasi masyarakat dalam pengelolaan dana desa di desa tumaluntung satu Kecamatan tareran Kabupaten Minahasa Selatan. https://Www.Neliti.Com/Id/Publications/ 161029/Partisipasi-Masyarakat-Dalam-Pengelolaan-Dana-Desa-Di-Desa.

Undang-undang. 2014. Tentang Dana Desa. http://www.keuangandesa.com/2017/04/dana-desa-menurutundang-undang-no-6-tahun.

Williamson, O., (1985) The Economic Institutions of Capitalism (New York, Free Press). https://pdfs.semanticscholar.org/a4d6/1a75c4b99d414084cc84f404e5

Yuyun, Y. (2015). Potensi Penyelewengan Alokasi Dana Desa Dikaji Menurut Peraturan Menteri Dalam Negeri Nomor 37 Tahun 2007 tentang Pengelolaan Keuangan Desa. Jurnal Mimbar Justitia. $1(02)$.

Zerubavel, E. 2004. Time Maps: Collective Memory and the Social Shape of the Past. Chicago: University of Chicago Press. 